University of Nebraska - Lincoln

DigitalCommons@University of Nebraska - Lincoln

USDA National Wildlife Research Center - Staff Publications
U.S. Department of Agriculture: Animal and Plant Health Inspection Service

January 2003

\title{
Monetary valuation methods for economic analysis of the benefit- costs of protecting rare wildlife species from predators
}

Richard M. Engeman

USDA-APHIS-Wildlife Services, s_r100@yahoo.com

Stephanie A. Schwiff

National Wildlife Research Center

Henry T. Smith

Florida Department of Environmental Protection

Bernice Constantin

USDA/APHIS/WS

Follow this and additional works at: https://digitalcommons.unl.edu/icwdm_usdanwrc

Part of the Environmental Sciences Commons

Engeman, Richard M.; Schwiff, Stephanie A.; Smith, Henry T.; and Constantin, Bernice, "Monetary valuation methods for economic analysis of the benefit-costs of protecting rare wildlife species from predators" (2003). USDA National Wildlife Research Center - Staff Publications. 88.

https://digitalcommons.unl.edu/icwdm_usdanwrc/88

This Article is brought to you for free and open access by the U.S. Department of Agriculture: Animal and Plant Health Inspection Service at DigitalCommons@University of Nebraska - Lincoln. It has been accepted for inclusion in USDA National Wildlife Research Center - Staff Publications by an authorized administrator of DigitalCommons@University of Nebraska - Lincoln. 


\title{
Monetary valuation methods for economic analysis of the benefit-costs of protecting rare wildlife species from predators
}

\author{
Richard M. Engeman ${ }^{1, *}$, Stephanie A. Shwiff ${ }^{1}$, Henry T. Smith ${ }^{2}$ \& Bernice Constantin ${ }^{3}$ \\ ${ }^{1}$ National Wildlife Research Center, 4101 LaPorte Avenue, Fort Collins, CO 80521-2154, U.S.A \\ ${ }^{2}$ Florida Department of Environmental Protection, Florida Park Service, 13798 SE Federal Highway, Hobe \\ Sound FL 33455, U.S.A. \\ ${ }^{3}$ USDA/APHIS/WS, 2820 East University Avenue, Gainesville, FL 32641, U.S.A. \\ * Author for correspondence
}

Key words: benefit-cost ratios, cost-efficacy, endangered species, predator management, threatened species

\begin{abstract}
Many threatened and endangered species are negatively impacted by predation. Management of the predators that are geographically and temporally in position to threaten species of concern can greatly aid in their conservation. However, decisions on management strategies are based within economic constraints, while the success of management actions is measured by wildlife resource improvement. Here, we review methods for applying monetary valuations for threatened and endangered species so that economic analyses of management actions can be used to help guide and evaluate management decisions. A variety of applied examples are provided to demonstrate the principles.
\end{abstract}

\section{Introduction}

Many endangered, threatened, or species of special concern are negatively impacted by other wildlife species. In particular, predation is a critical threat to many endangered or even locally rare species (Hecht \& Nickerson 1999). In today's environments, predation losses can have increased deleterious impact due to the compounding effects of, among other things, habitat loss and altered predator communities (Reynolds \& Tapper 1996). For example, raccoons (Procyon lotor) cause substantial destruction of sea turtle nests throughout the southeastern United States (Stancyk 1982), making them an example of a locally over-abundant native vertebrate that impacts the conservation of endangered species (e.g., Garrott et al. 1993). Similarly, native red-tailed hawks (Buteo jamaicensis) and pearly eyed thrashers (Margarops fuscatus), as well as exotic black rats (Rattus rattus) are prominent predators of Puerto Rican parrots (Amazona vittata), one of the world's most endangered birds (U.S. Fish and Wildlife Service 1999). Coyotes (Canis latrans) severely impact the success of black-footed ferret (Mustela nigriceps) reintroductions (e.g., Utah Division of Wildlife Resources 1995). Red foxes (Vulpes vulpes) and feral cats (Felis catus) are exotic species that have been implicated in the extinction and extensive range reductions of a variety of native Australian wildlife (Burbidge \& McKenzie 1989, Dickman 1996). Likewise, brown tree snakes (Boiga irregularis) are exotic predators that have devastated the fauna on Guam, causing the extinction of all but three forest bird species, which are now highly endangered (Savidge 1987; Engeman \& Vice 2001), as well as severely impacting native bat (Wiles et al. 1995) and lizard (Rodda \& Fritts 1992) populations.

A logical consideration to aid in the conservation of rare species negatively impacted by predators is to manage those predators that are geographically and temporally in position to threaten the rare species. Funding is finite for the recovery and conservation of rare and endangered species and must be carefully applied to maximize the positive impact on the protected species. Damage reduction efforts that target the depredating species are carried out to varying degrees for each of the examples above. Raccoons 
are managed at many marine turtle nesting beaches in Florida (e.g., Engeman et al. 2003a), pearly-eyed thrashers and black rats are managed in the Caribbean National Forest in the vicinities of Puerto Rican parrot nests (Cano 2002), coyotes and other predators often are removed prior to and after black-footed ferret releases (e.g., Utah Division of Wildlife Resources 1995), massive baiting campaigns are waged against red foxes in Australia (e.g., Armstrong 1998), and well in excess of \$1 million annually is applied to control the spread of brown tree snakes from Guam to other vulnerable locations, and to reclaim areas on Guam for protection and/or reintroduction of endangered species (Engeman \& Vice 2001).

Predator management is widely applied to protect threatened and endangered species, but the corresponding efficacy data often result from management actions rather than research experiments (e.g., Florida Park Service 2001), and therefore, usually do not appear in the scientific literature as a matter of practice. Nevertheless, such population data are important to obtain and review, because an analytical examination of the economics of predator management as an endangered species recovery or enhancement technique can provide managers with a logical working basis for selecting and implementing methodologies aimed at conserving the species. While the direct costs for a damage reduction strategy are relatively easy to identify and quantify because they can be measured by the budgetary outlay for implementation, the rewards from those budgetary allocations are measured in terms of wildlife resource improvements, such as population growth. To effectively evaluate the returns, the rewards from the expenditures must be in the same metric as the expenditures. That is, the resource improvement must also be monetarily valued. Herein, we consider some approaches for monetarily valuing the benefits to wildlife resources from damage reduction programs. We use examples such as the aforementioned to demonstrate valuation approaches for rare species, and their application in economic analyses of predator management objectives.

\section{Monetary Valuation}

Determination of monetary values for rare species is not a straight-forward nor precise process. As an illustration, consider that values of endangered or threatened species have been deemed 'incalculable' in U.S. Supreme Court case law (Tennessee Valley Authority vs. Hill 1978), the opinion going so far as to say "it would be difficult for a court to balance the loss of a sum certain - even $\$ 100$ million against a congressionally declared 'incalculable' value, even assuming we had the power to engage in such a weighing process, which we emphatically do not." Despite that assessment, infinite or astronomically high monetary species valuations would be unlikely to be widely viewed as credible. Nevertheless, conservative monetary values for rare species can be estimated through several means. Following, we examine and provide examples for three means of obtaining societal values on the worth of rare species to be protected from depredating species.

\section{Contingent Valuation}

Contingent valuation is a method of valuation in which information regarding the benefits and costs of a natural resource are elicited through the use of a survey instrument (e.g., Loomis \& Walsh 1997). This method can be used to measure people's willingness to pay (WTP) for wilderness recreation or natural resources in a hypothetical market. The respondent is asked to estimate the maximum amount he would pay for a recreation opportunity or resource if it were available. The payment method can be adjusted to fit the resource in question; examples include higher prices for natural area entrance fees or hunting and fishing licenses, higher trip costs, and taxes. WTP often varies greatly between payment methods. Question format, as in any survey, also can have a large influence on the results. Common formats include open-ended questions, payment cards, iterative bidding, and dichotomous choice and referenda (Loomis \& Walsh 1997). Each method has its benefits and shortcomings, and it is important to recognize the limitations of contingent valuation surveys. Because the scenarios are hypothetical, the validity of the responses to a contingent valuation is unsure. Therefore, the results may not reflect the true WTP, either because people do not have a realistic sense of how much they would pay, or because they have incentives to dishonestly report their WTP (Loomis \& Walsh 1997). 
To use contingent valuations of rare species in an economic analysis first requires that such survey values exist or can be generated, and that the data were obtained using statistically valid survey design principles, data collection procedures, and data analyses. Given the above, the results must be geographically and temporally relevant to the economic analyses at hand. For example, Whitehead (1992), through a contingent valuation survey, appraised marine turtle values at $\$ 32$. However, in an economic analysis of four approaches for reducing predation on marine turtle nests at a National Wildlife Refuge in Florida, Engeman et al. (2002) found that the Whitehead (1992) turtle values would have been inappropriate to generalize to their situation. First, there were severe limitations in the Whitehead (1992) survey design in terms of the maximum monetary values that turtles could obtain. Furthermore, use of those results would have been an extrapolation beyond the inference space of the data, both geographically and temporally. The Whitehead (1992) survey was a small sample from North Carolina, whereas the Engeman et al. (2002) study was in east-central Florida. In particular, the city bordering the Florida refuge, Jupiter Island, was considered the wealthiest in the U.S. (Nguyen 2000), thus making it unlikely that its residents would value turtles as low as in the Whitehead (1992) survey. Furthermore, the Whitehead (1992) results were approximately a decade earlier than the Engeman et al. (2002) economic analysis, making them temporally as well as geographically disjunct from the situation at hand. If relevant contingent valuation data are not available, another means for valuing species must be applied in economic analyses. Designing, implementing, and analyzing a contingent valuation survey would most likely be too time consuming and costly to provide the necessary information in a timely manner as part of an economic analysis to support management decisions in the near-term.

\section{Legislatively Designated Values}

State wildlife and fisheries management agencies use estimates of economic values based on contributions to the economy by individual game species to derive their monetary values (Bodenchuk et al. 2002). These economic values serve as the basis for civil financial penalties for illegal kills resulting from such acts as poaching, environmental contamination, or other 'takes' (Bodenchuk et al. 2002). However, rare and endangered species do not have civil financial penalties assigned in relation to their contributions to the economy as 'renewable' resources, because they are rarely, if ever, exploited in a financially measurable fashion such as through the sale of hunting or fishing licenses and sportsman equipment.

While not exploited in an easily quantifiable sense, rare and endangered species are, however, almost universally protected with civil penalties set forth legislatively. More than likely, such species will have more than one value available from multiple enabling legislations (e.g., United States federal and individual state laws). Multiple applicable civil penalties pose a dilemma as to which to incorporate into an economic analysis. A conservative benefit-cost analysis is obtained when the minimal applicable value is employed. However, this could be a radical under-valuation for a species, especially when considering that all civil financial penalties from the different enabling legislations could apply simultaneously. Consider again the example of predator depredations on marine turtle nests in Florida by Engeman et al. (2002). Their analyses chose the conservative route of applying a minimum legislative value of $\$ 100$ from Florida statutes. This valuation resulted in a demonstration of an $\$ 8.4$ million improvement in hatchling turtle return for a $\$ 5000$ control contract. However, the Florida Wildlife Code specified a value of $\$ 500$ per life unit, and the federal Endangered Species Act (ESA) allows for civil penalties up to $\$ 25,000$ per life unit (Engeman et al. 2002). Thus, the monetary benefits accrued from the predator management approaches could have been as much as 250 times greater.

Listed as a threatened species by the state of Florida, least terns (Sterna antillarum) also nest on the same refuge beach at the same time as the turtles (Engeman et al. 2002). For this species, there is not an applicable $\$ 100$ value in Florida statutes, but the Florida Wildlife Code value of $\$ 500$ applies. In addition, the federal Migratory Bird Treaty Act (MBTA) value of $\$ 2000$ also applies. It is interesting to note that for the federally listed (ESA) populations of this species (e.g., California least tern) ESA values of up to $\$ 25,000$ would apply. Thus, we see that birds and turtles on the same refuge beach are covered by multiple 
state and federal legislations and multiple valuations through civil penalties. As a unifying point, the use of minimal values often still results in large benefit-cost ratios (BCRs). Engeman et al. (2002) used the minimal marine turtle valuation to show dramatic returns for management actions, as did Shwiff et al. (2003) for valuing actions to protect royal terns (Sterna maxima). Additional analyses using the higher legislative valuations better define the upper limit of societal BCRs for protecting rare species from depredating animals.

\section{Breeding Costs}

Captive breeding is not only a management strategy for assisting the recovery of a rare species, but it also provides data for placing a value on a species. The use of captive breeding costs as a means for monetarily valuing rare species is a simple concept, because those monies spent to produce animals in captivity are an explicit and empirical demonstration of a WTP for new animals. The costs of captive breeding divided by the number of healthy individuals produced defines a value for the species (e.g., Bodenchuk et al. 2002). For example, the value calculated for black-footed ferret production in 1995 in this manner was $\$ 29,132$ per animal (Bodenchuk et al. 2002). However, the valuing process is not quite as straight-forward as this seems. Sometimes, there are multiple captive breeding facilities for the same species, each with its own budget (e.g., Engeman et al. 2003b). A facility may remain in operation year-in and year-out, but its temporal budget and animal production may fluctuate substantially. Thus, budget and production variation among captive breeding sites for a particular species, and among years within a site, can result in substantial variation in the value for a particular species. The selection of a particular value for a benefit-cost or net benefit analysis must be carefully weighed against the objectives of the analysis. The most conservative analysis is obtained if the minimum cost per production of a healthy individual is used, whereas use of the maximum value provides the empirical peak expenditure to produce an individual of the species. Use of the median value for an individual provides an analysis representing the central tendency for valuing the species. As an example, Engeman et al. (2003b) conducted an economic analysis of predator management for protecting Puerto Rican parrots from predators. They used 5 years of data on the production costs and the corresponding number of healthy fledglings produced for three highly managed populations during the years 1997-2001, resulting in values ranging from $\$ 2415$ to $\$ 100,000$ per individual. The median annual value from combining the expenditures each year for the three populations was $\$ 25,500$ per parrot, which provided sufficient information for lucid management decisions from a conservative analysis. Application of the maximum annual value for the three populations combined left little doubt that simultaneous management of the predator species was an economically rewarding method for helping to conserve the species.

\section{Discussion}

Once the monetary values of the protected species have been established, economic analyses can be used to evaluate whether predator management is a fiscally responsible approach for species conservation, or it can be used to provide cost-efficacy comparisons among multiple approaches. For example, the Engeman et al. (2002) economic analysis compared and found clear distinctions among four predator management approaches for protecting marine turtles. Similarly, method development for the control of brown tree snakes has been ongoing for a number of years (Engeman \& Vice 2001), and Clark et al. (in review) provided an economic analysis demonstrating a dramatic improvement in cost-efficacy and cost-efficiency by using a newly-developed toxic baiting approach (Savarie et al. 2001) over trapping, which has been the primary operational snake removal method for the past decade (Engeman \& Vice 2001).

Benefit-cost analysis provides a useful tool in assessing alternate methods of valuing the benefits and costs of protecting rare wildlife species from predators. However, in some cases it is difficult for the analyst to attach monetary values to the major benefits of a particular method, making it impossible to estimate the net benefits. In this case if the analyst can construct a ratio of the quantitative, but non-monetized benefits, and the total dollar costs, then the appropriate methodology is to use a cost-effectiveness analysis (Boardman et al. 1996). 
Under this type of analysis, the best management strategy is identified by its ability to achieve a certain goal at the lowest cost. Another analytical consideration important to benefit-cost analysis is to identify the potential physical impacts of alternative approaches, and specify the measurement indicator that will be used assess these impacts. Ideally, these predicted impacts can be evaluated over the lifetime of the project to accurately incorporate all of the benefits and costs of a project (Boardman et al. 1996). For example, a predator management approach would have a direct impact on the population dynamics of the predator being managed and the wildlife prey. When possible, estimation of these effects for inclusion in the analysis provides the most comprehensive understanding of the management effort.

Another complicating factor for precise economic analyses of predator management can occur when the predator management is simultaneously aimed at protecting multiple taxa of animals. For example, a coalition of state and federal properties in Florida's 'panhandle' region pools resources to contract for the management of a variety of predator species that imperil threatened and endangered reptile, bird and mammal species (e.g., Northwest Florida Partnership 2000). Marine turtle nests are protected from depredations by raccoons, coyotes, and feral swine (Sus scrofa), and shorebird nests are protected from the same predators as well as red fox and feral cats. Endangered beach mice are protected from direct predation by coyotes, red foxes, feral cats, and gray foxes (Urocyon cinereoagenteus), while endangered red wolves (Canis rufus) are protected from interbreeding with coyotes (such congenetic mating events could genetically pollute the limited remaining red wolf breeding stock). The total cost for the predator management is readily available because it is conducted by contract. The monetary contributions by each partner property are similarly available if an economic analysis for a particular property is desired. A mixture of state and federal civil penalties are available for all species, and the red wolf also is bred in captivity, so empirical production costs can be calculated. However, population productivity data are available for only a fraction of the protected species. Furthermore, the different properties have population data on different subsets of the protected species. Marine turtle data are the most consis- tently available, whereas only anecdotal observations, but no population or production data are available for the beach mouse species. Population data on shorebirds is limited to (threatened) snowy plovers (Charadrius alexandrinus), and that is available from only one property. Red wolves are located at only one property where their numbers are highly managed and well-known. Thus, an economic analysis of the benefits from predator management for the potpourri of properties and protected taxa is incomplete in that it can only be carried out using the population data available from a subset of species protected. Therefore, the results present a known lower bound for the overall benefits to all taxa across all properties.

By necessity, economic analyses take a 'shopping cart' approach to valuing the species being protected from predators, whereby a 'price tag' is applied to the individual of each species. The credibility of an analysis hinges on the logical application of a valuation procedure. Conservative benefit-cost analyses using lower species values tend to lead to greater acceptance of the results, but should be accompanied by the knowledge that the actual benefit-cost ratio is likely to be much higher. However, estimated replacement costs for threatened and endangered species do not compensate for the immediate predation loss of biotic potential within demes, nor for the more consequential, irretrievable loss of pooled genetic variation through subsequent generations. Unfortunately, it is impossible to ascribe monetary value to the loss of random mating events and the infinite possibilities for genetic recombination associated with them. Considerations such as these lend credence to the U.S. Supreme Court assessment of 'incalculably' high values for threatened and endangered species.

\section{Acknowledgements}

The authors thank K. Fagerstone and J.R. Mason for their helpful reviews.

\section{References}

Armstrong, R. (1998) Western Shield - bringing back wildlife from the brink of extinction. Aust. Vertebrate Pest Conf. 11, 265-73. 
Boardman, A.E., Greenberg, D.H., Vining, A.R. and Weimer, D.L. 1996. Cost-Benefit Analysis: Concepts and Practice, Prentice Hall, Upper Saddle River, New Jersey, pp. 36-7.

Bodenchuk, M.J., Mason, J.R. and Pitt, W.C. (2002) Economics of predation management in relation to agriculture, wildlife, and human health and safety. In L. Clark (ed) Proceedings of the 1st International Symposium on the Economics of Wildlife Damage Management. CO: Colorado State University, Fort Collins. pp. 80-90.

Burbidge, A.A. and McKenzie, N.L. (1989) Patterns in the decline of Western Australia's vertebrate fauna: Causes and conservation implications. Biological Conservation 50, 143-98.

Cano, F. (2002) USDA Forest Service Puerto Rican Parrot Management Summary for March through May 2002 on the Caribbean National Forest. U.S. Forest Service, Puerto Rico. 4 pp.

Clark, L., Savarie, P.J., Shivik, J.A. and Breck, S. (in review) Efficacy, effort, and cost comparisons of trapping and acetaminophen-baiting for control of brown treesnakes on Guam. Journal of Wildlife Management.

Dickman, C.R. (1996) Impact of exotic generalist predators on the native fauna of Australia. Wildlife Biology 3, 165-75.

Engeman, R.M. and Vice, D.S. (2001) Objectives and integrated approaches for the control of brown tree snakes. Integr. Pest Manage. Revi. 6, 59-76.

Engeman, R.M., Martin, R.E., Constantin, B., Noel, R. and Woolard, J. (2003a) Monitoring predators to optimize their management for marine turtle nest protection. Biol. Cons. 113, 171-178.

Engeman, R.M., Shwiff, S.A., Constantin, B. and Cano, F. (2003b) An economic assessment of the potential for predator management to benefit Puerto Rican parrots. Ecol. Econ. 46, 283-292.

Engeman, R.M., Shwiff, S.A., Constantin, B., Stahl, M. and Smith, H.T. (2002) An economic analysis of predator removal approaches for protecting marine turtle nests at Hobe Sound National Wildlife Refuge. Ecol. Econ. 42, 469-78.

Florida Park Service (2001) 2000-2001 Resource Management Annual Report July 1, 2000-June 30, 2001. Florida Department of Environmental Protection, Florida Park Service, Tallahassee, Florida.

Garrott, R.A., White, P.J. and White, C.A. (1993) Overabundance: An issue for conservation biologists? Conservation Biology 7, 946-9.

Hecht, A. and Nickerson, P.R. (1999) The need for predator management in conservation of some vulnerable species. Endangered Species Update 16, 114-8.
Loomis, J.B. and Walsh, R.G. (1997) Recreation Economic Decisions: Comparing Benefits and Costs, 2nd edn. Venture Publishing, Inc. State College, Pennsylvania, pp. 369410.

Nguyen, L.N. (2000) America's richest towns. Worth Magazine 2000 (June), 88.

Northwest Florida Partnership (2000) Partnership results in protection of sea turtle nests through control of non-native predators on coastal public lands across NW Florida, In abstracts: USA. 20th Annual Symposium on Sea Turtle Biology and Conservation. Florida Fish and Wildlife Conservation Commission, Florida Marine Research Institute, St. Petersburg. p. 165.

Reynolds, J.C. and Tapper, S.C. (1996) Control of mammalian predators in game management and conservation. Mammal Rev. 26, 127-56.

Rodda, G.H. and Fritts, T.H. (1992) The impact of the introduction of the colubrid snake Boiga irregularis on Guam's lizards. J. Herpetol. 26, 166-74.

Savarie, P.J., Shivik, J.A., White, G.C. and Clark, L. (2001) Use of acetaminophen for large scale control of brown treesnakes. J. Wildlife Manage. 65, 356-65.

Savidge, J.A. (1987) Extinction of an island forest avifauna by an introduced snake. Ecology 68, 660-8

Shwiff, S.A., Engeman, R.M., Bard, A.M., Harbor, T.V., Heath, G.W. and Smith, H.T. (2003). An economic analysis of a simple structural method to reduce road-kills of royal terns at bridges. Ecol. Econ. 39, 250-253.

Stancyk, S.E. (1982) Non-human predators of sea turtles and their control. In K.A. Bjorndal (ed), Biology and Conservation of Sea Turtles, pp. 139-152. Smithsonian Institution Press, Washington, DC.

Tennessee Valley Authority vs Hill (1978) 437 U.S. 153

U.S. Fish and Wildlife Service (1999) Technical/Agency Draft Revised Recovery Plan for the Puerto Rican Parrot (Amazona vittata). U.S.F.W.S. Region 4, Atlanta, GA. 77 pp.

Utah Division of Wildlife Resources (1995) Cooperative plan for the reintroduction and management of black-footed ferrets in Coyote Basin, Uintah County, Utah. Utah Division of Wildlife Resources, Salt Lake City, Utah.

Whitehead, J.C. (1992) Ex ante willingness to pay with supply and demand uncertainty: Implications for valuing a marine turtle protection programme, Appl. Econ. 24, 981-8.

Wiles, G.J., Aguon, C.F., Davis, G.W. Grout, D.J. (1995) The status and distribution of endangered animals and plants in northern Guam. Micronesica 28, 31-49. 